\title{
From Jefferson to Banneker: The Intersection of Race, Demographic Change, and School Naming Practices in Kansas City's Segregated School System, 1940-1953
}

\section{Peter William Moran}

This article examines the impact of African American migration into Kansas City, Missouri, on the city's segregated school system in the 1940s and early 1950s. Substantial increases in the number of African American elementary school-age children produced chronic overcrowding in the segregated black schools, which was not easily relieved due to the legal requirement to operate racially segregated schools. In order to address the crowding, the school district was compelled on four occasions in the late 1940s and early 1950s to convert an entire school from white use to African American use. In each case, the school district took the symbolic step of changing the name of the school so that it was clearly identifiable as a school for African American students. The school district's practice of renaming schools coded those schools by race and further signaled that the surrounding area bad become a black neigbborbood.

In his 1965 autobiography, Malcolm X noted that when he was in an unfamiliar city for the first time, the simplest method of locating the predominantly African American neighborhood was to pick up a city directory and find the address for a school named after Abraham Lincoln. At first glance it may not seem unusual that a historical figure of Lincoln's stature would have schools named in his honor. What Malcolm found interesting, indeed quite useful when trying to find one's way in a city, was the practice of naming predominantly or exclusively black schools for the Great Emancipator. ${ }^{1}$ Kansas City, Missouri, was among those cities in which applying Malcolm X's method would have produced the desired result. Since 1887,

Peter William Moran is a professor in the School of Teacher Education at the University of Wyoming. He teaches courses in social studies methods, arts integration, and history of education. He would like to thank Steve Bialostok and students in the honor's program Race and Racism course, and the HEQ reviewers and editors for their valuable feedback on this article.

${ }^{1}$ Malcolm X and Alex Haley, The Autobiography of Malcolm X (New York: Grove Press, 1965), 79. 
Lincoln High School had served black students in the heart of Kansas City's large African American neighborhood.

Naming places, such as schools, is an act grounded in cultural meanings and values considerations. ${ }^{2}$ At one level, when public officials choose to name schools for individuals, they plainly make a statement regarding whom they consider to be historically or culturally significant. Beyond those considerations, school officials also endorse a particular individual as possessing the appropriate qualities to have his or her name bestowed upon a school, while at the same time rejecting other possible candidates for such recognition. ${ }^{3}$ In Kansas City, during the era of segregated schooling, there was also a racially specific quality to the naming of school buildings. While white students attended schools named for notable figures across a broad sweep of American history and culture, black students attended schools with names that clearly designated that the school was for use by African Americans. Essentially, school names were code for the race of the students and the neighborhood that the school served. This does not make Kansas City unique. Numerous cities and towns followed similar racially specific practices in selecting names for schools established to serve African American students.

In Kansas City, the practice of using racially specific names for segregated black schools extended through the first half of the twentieth century as the city's demographics changed. Due to population shifts and the substantial growth of the African American population in Kansas City, it became necessary periodically to convert a school from white to black use. In each instance, the school officials' predilection that a neighborhood school for African American children be racially identifiable by virtue of its name became patently obvious. On three occasions in the 1910s and 1920s, school officials converted schools from white use to black and took the additional step of selecting

${ }^{2}$ George R. Stewart, Names on the Land: A Historical Account of Place-Naming in the United States (Boston: Houghton Mifflin, 1958); Sanford Levinson, Written in Stone: Public Monuments in Changing Societies (Durham, NC: Duke University Press, 1998); and Stephen Greenblatt, Marvelous Possessions: The Wonder of the New World (Chicago: University of Chicago Press, 1991).

${ }^{3}$ Levinson, Written in Stone, 11-19, 79-87, 135; Derek H. Alderman, "School Names as Cultural Arenas: The Naming of U.S. Public Schools after Martin Luther King, Jr.," Urban Geography 23, no. 7 (Nov. 2002), 601-26; Roger W. Stump, "Toponymic Commemoration of National Figures: The Cases of Kennedy and King," Names 36, no. 3-4 (Dec. 1988), 203-16; Lawrence D. Berg and Robin A. Kearns, "Naming as Norming: 'Race,' Gender, and the Identity Politics of Naming Places in Aotearoa/New Zealand," Environment and Planning D: Society and Space 14, no. 2 (Feb. 1996), 99-122; and Jay Goldstein, "National Identification in Winnipeg: An Analysis of School-Naming Events from 1881 to 1976," Prairie Forum 3, no.2 (Fall 1978), 117-30. 
more appropriately black names for the schools. ${ }^{4}$ Four more schools were similarly converted during the 1940s and early 1950s. ${ }^{5}$ This article explores the relationships between the demographic changes produced by thousands of African American families moving into Kansas City, the severe overcrowding in segregated black schools that resulted from population shifts, the subsequent conversion of schools from segregated white to black use, and the renaming of those schools.

On a broader level, this article also examines how demographic change created additional complications for managing segregated school systems in Kansas City and several other cities in the border states. In short, the large numbers of African Americans moving into border state cities during the 1940s and 1950s resulted in extraordinary crowding in the segregated schools that served black students. ${ }^{6}$ In school districts not constrained by state law to maintain racial separation, the solution to the crowding issue could be dealt with by busing students or through adjusting attendance zone boundaries around the impacted schools to reassign students from crowded schools to nearby schools with available space. The difficulty in addressing the overcrowding in a school that was segregated by law stemmed from the need to convert an entire school building from white use to black. School conversions were frequently controversial, and the school district generally delayed such action until crowding in the segregated black schools reached critical levels and demanded relief. The inflexible nature of the segregated school system, school officials' slovenly responses in addressing issues of crowding, and the school district administration's inability to respond proactively to population shifts caused additional hardships for African American students in Kansas City and elsewhere. The second aim of this article is to explore the little examined problem of how crowding issues were exacerbated by the organizational structure of segregated school systems and by

${ }^{4}$ Previous conversions of schools from white use to black use: William Cullen Bryant Elementary converted to Wendell Phillips Elementary in 1912; Samuel Morse Elementary converted to Charles Sumner Elementary in 1927; Ralph Waldo Emerson Elementary converted to William Lloyd Garrison Elementary in 1929; Discontinued Schools File, Kansas City (MO) School District Records, Kansas City (MO) School District Central Administration Building (hereafter cited as KCMSD Archives).

${ }^{5}$ These include Booker T. Washington Elementary, George Washington Carver Elementary, Benjamin Banneker Elementary, and D.A. Holmes Elementary. See Histories of Individual Schools Files, KCMSD Archives.

${ }^{6}$ Brett V. Gadsden, Between North and South: Delaware, Desegregation, and the Myth of American Sectionalism (Philadelphia: University of Pennsylvania Press, 2013); and Clarence Lang, Grassroots at the Gateway: Class Politics and Black Freedom Struggle in St. Louis, 1936-75 (Ann Arbor: University of Michigan Press, 2009). 
the reluctance of school administrators to take action in a timely manner.

\section{The Second Great Migration, Shifting Demographics and Crowded Schools}

Between the 1940s and the 1970s, more than five million African Americans moved from former Confederate states to cities in the North, Midwest, and West, a massive demographic shift commonly referred to as the Second Great Migration. This migration's scale and scope was considerably larger and more widespread than what had preceded it and, when coupled with the growth of largely white suburban communities during the same period, profoundly changed the racial composition of America's cities. The Great Migration was fueled by prospects of greater economic opportunity in the cities and escape from the grinding poverty and exploitation of the sharecropping system. Moreover, the migration promised some relief from the political disenfranchisement, rigid segregation codes, lynchings, violence, and racial injustice of the old South as well as expanded educational opportunities for African American children. ${ }^{7}$

As Table 1 illustrates, a number of cities outside the South witnessed substantial African American population growth in the 1940s and 1950s. Indeed, most of the cities in the table saw their black populations double or more than double between the 1940 and 1960 censuses. Arriving in the city, African American migrants were confronted with widespread residential segregation. With few other options, they gravitated toward established black neighborhoods, and housing pressure in African American residential areas became intense. Coping with the volume of this migration placed considerable strain on the available housing stock, employment markets, city services, and urban infrastructure. Moreover, because many of these migrants

${ }^{7}$ Douglas A. Blackmon, Slavery by Another Name: The Re-Enslavement of Black Americans from the Civil War to World War II (New York: Doubleday, 2008); Arnold R. Hirsch, Making the Second Ghetto: Race and Housing in Chicago, 1940-1960 (Chicago: University of Chicago Press, 1998); Michael J. Klarman, From Jim Crow to Civil Rights: The Supreme Court and the Struggle for Racial Equality (New York: Oxford University Press, 2004); Nicholas Lemann, The Promised Land: The Great Black Migration and How It Changed America (New York: Vintage Books, 1992); Stanley Lieberson, A Piece of the Pie: Blacks and White Immigrants Since 1880 (Berkeley: University of California Press, 1980); Karl E. Taeuber and Alma F. Taeuber, Negroes in Cities: Residential Segregation and Neighborhood Change (Chicago: Aldine, 1965); Stewart E. Tolnay, "The African American 'Great Migration' and Beyond," Annual Review of Sociology 29 (2003), 209-32; and Isabel Wilkerson, The Warmth of Other Suns: The Epic Story of America's Great Migration (New York: Random House, 2010). 
Table 1. Population Change in Selected Cities, 1940-1960

\begin{tabular}{|c|c|c|c|c|c|c|c|c|c|}
\hline \multirow[b]{2}{*}{ City } & \multicolumn{3}{|c|}{1940} & \multicolumn{3}{|c|}{1950} & \multicolumn{3}{|c|}{1960} \\
\hline & $\begin{array}{c}\text { Total } \\
\text { Population }\end{array}$ & $\begin{array}{c}\text { Black } \\
\text { Population }\end{array}$ & $\begin{array}{c}\% \\
\text { Black }\end{array}$ & $\begin{array}{c}\text { Total } \\
\text { Population }\end{array}$ & $\begin{array}{c}\text { Black } \\
\text { Population }\end{array}$ & $\begin{array}{c}\% \\
\text { Black }\end{array}$ & $\begin{array}{c}\text { Total } \\
\text { Population }\end{array}$ & $\begin{array}{c}\text { Black } \\
\text { Population }\end{array}$ & $\begin{array}{c}\% \\
\text { Black }\end{array}$ \\
\hline \multicolumn{10}{|c|}{ Border State Cities } \\
\hline $\begin{array}{l}\text { Kansas City, } \\
\text { MO }\end{array}$ & 400,178 & 41,547 & 10.4 & 456,622 & 55,682 & 12.2 & 475,539 & 83,146 & 17.5 \\
\hline St. Louis, MO & 816,048 & 108,765 & 13.3 & 856,796 & 153,766 & 17.9 & 750,026 & 214,377 & 28.6 \\
\hline Baltimore, MD & 859,100 & 165,843 & 19.3 & 949,708 & 225,099 & 23.7 & 939,024 & 325,589 & 34.7 \\
\hline Washington DC & 663,091 & 187,266 & 28.2 & 802,176 & 280,803 & 35 & 763,956 & 411,737 & 53.9 \\
\hline Louisville, KY & 319,077 & 47,158 & 14.8 & 369,129 & 57,657 & 15.6 & 390,639 & 70,075 & 17.9 \\
\hline Wilmington, DE & 112,504 & 14,256 & 12.7 & 110,356 & 17,202 & 15.6 & 95,827 & 24,922 & 26 \\
\hline \multicolumn{10}{|c|}{ Select Cities Outside the South } \\
\hline New York City & $7,454,995$ & 458,444 & 6.1 & $7,891,957$ & 747,608 & 9.5 & $7,781,984$ & $1,087,931$ & 14 \\
\hline Chicago & $3,396,808$ & 277,731 & 8.2 & $3,620,962$ & 492,265 & 13.6 & $3,550,404$ & 812,637 & 22.9 \\
\hline Philadelphia & $1,931,334$ & 250,880 & 13 & $2,071,605$ & 376,041 & 18.2 & $2,002,512$ & 529,240 & 26.4 \\
\hline Detroit & $1,623,452$ & 149,119 & 9.2 & $1,849,568$ & 300,506 & 16.2 & $1,670,144$ & 482,223 & 28.9 \\
\hline Los Angeles & $1,504,277$ & 63,744 & 4.2 & $1,970,358$ & 171,209 & 8.7 & $2,479,015$ & 334,916 & 13.5 \\
\hline Cleveland & 878,336 & 84,504 & 9.6 & 914,808 & 147,847 & 16.2 & 876,050 & 250,818 & 28.6 \\
\hline Pittsburgh & 671,659 & 62,216 & 9.3 & 676,806 & 82,453 & 12.2 & 604,332 & 100,692 & 16.7 \\
\hline Cincinnati & 455,610 & 55,593 & 12.2 & 503,998 & 78,196 & 15.5 & 502,550 & 108,754 & 21.6 \\
\hline Indianapolis & 386,972 & 51,142 & 13.2 & 427,173 & 63,867 & 15 & 476,258 & 98,049 & 20.6 \\
\hline
\end{tabular}

Campbell Gibson and Kay Jung, Historical Census Statistics on Population Totals by Race, 1790-1990 (Feb. 2005), https://www.census.gov//content/dam/Census/library/ working-papers/2002/demo/POP-twps0056.pdf. 
were young people and young families, the migration also produced extreme pressure on the public school systems in these cities. ${ }^{8}$

With respect to school systems, each of the cities in the table experienced significant enrollment growth, particularly in the elementary grades. For example, in the Detroit public schools, where crowding was a chronic problem throughout the 1940s and 1950s, enrollment in kindergarten through sixth grade rose by more than twenty-six thousand students between 1940 and 1950, an increase of almost 20 percent. ${ }^{9}$ Detroit's schools had extreme difficulty absorbing the rising enrollments, and the district's troubled fiscal situation precluded school officials from committing the necessary resources to a program of capital improvements, renovations, and new school construction. In attempting to deal with crowding, Detroit school officials made annual adjustments to school attendance zones in order to redistribute students more evenly across schools, bused students from crowded schools to schools outside their neighborhoods that had available classroom space, and implemented half-day schedules at some schools. These solutions were certainly not ideal, but they did provide the district with flexibility from one year to the next in coping with crowded schools and the city's changing demographics. ${ }^{10}$ Similar adjustments were made in Chicago; Flint, Michigan; and other cities. ${ }^{11}$ This is not to say that crowding in predominantly black schools was not a problem in northern and midwestern cities. Rather, the point is that those cities had a palette of potential policy measures for addressing crowding in the schools. In Kansas City and other border state cities, the possible interventions for addressing crowding were considerably narrower.

A principal difference between Detroit and Kansas City or other border state cities listed in Table 1 is that, in dealing with crowded schools, the work of school district administrators in the border states was complicated by state constitutional mandates to operate racially segregated schools. Whereas school officials in northern, midwestern, and western cities had the latitude to reassign or bus students from crowded schools to schools with space available regardless of the racial

${ }^{8}$ Hirsch, Making the Second Ghetto; Taeuber and Taeuber, Negroes in Cities; Lemann, The Promised Land; Jeffrey Mirel, The Rise and Fall of an Urban School System: Detroit, 1907-1981 (Ann Arbor: University of Michigan Press, 1993), 152-56, 218-21; and Andrew R. Highsmith, Demolition Means Progress: Flint, Michigan, and the Fate of the American Metropolis (Chicago: University of Chicago Press, 2015), 54-77.

${ }^{9}$ Mirel, Rise and Fall of an Urban School System, Appendix, Tables 1 and 2, np.

${ }^{10}$ Mirel, Rise and Fall of an Urban School System, 192-95, 240-41.

${ }^{11}$ Kathryn N. Neckerman, Schools Betrayed: Roots of Failure in Inner City Schools (Chicago: University of Chicago Press, 2007), 7-29, 81-106; and Highsmith, Demolition Means Progress, 54-77. 
composition of the students or the schools, border state school officials were required by law to maintain racially segregated schools. In the border states, African American students in a grossly overcrowded elementary school could not simply be reassigned to a nearby white school that was operating at 50 percent of capacity. In order to relieve crowding in African American schools while also complying with the legal requirement to operate segregated schools, school officials were compelled to convert entire schools from white use to black use.

In Kansas City during the 1940s and early 1950s, school conversions were controversial and had implications beyond the affected schools. School officials were extremely wary of taking action that could be perceived as impacting the real estate market and perhaps spurring the rapid transition of neighborhoods from white to African American. Consequently, the school board and the school district's central administration consistently delayed conversions and consigned African American students to schools that grew increasingly crowded with each passing year. School officials provided relief in African American schools only when overcrowding had reached critical proportions and after the process of residential transition had largely run its course in the affected neighborhoods. Although the focus of this article is Kansas City, it is important to recognize that the problems of when to convert a school to African American use, which school to convert, and assessing the impact of school conversions on the surrounding neighborhood were not unique to Kansas City. Cities across the border states experienced significant in-migration of African Americans during the 1940s and 1950s, including tens of thousands of school-age children. Those school systems also wrestled with thorny issues of how to address crowding in schools serving black children. ${ }^{12}$

\section{The Racial Landscape of Kansas City}

In 1940, Kansas City's population totaled slightly more than 400,000, about 41,500 of whom were African Americans. More than 75 percent of the city's black population lived in a single large neighborhood just east and south of the central business district. This central neighborhood was roughly the shape of a diamond, the north-south axis being Woodland Avenue between Eighth and Twenty-Ninth Streets, and the east-west axis being Eighteenth Street between Indiana Avenue and Oak Street. At the heart of the large central area was the Eighteenth and Vine neighborhood, with its concentration of African American-owned businesses, banks, theaters, and churches; the offices

\footnotetext{
${ }^{12}$ Gadsden, Between North and South, 59-64.
} 
of the city's black newspaper, The Call; the jazz clubs that made Kansas City a hub of the nation's music scene; and Municipal Stadium, the home field of the storied Kansas City Monarchs of baseball's Negro American League. Outside the large central neighborhood, the great majority of the remaining African American residents lived in either the small, racially mixed neighborhoods on the city's west side or in the Citadel and Dunbar neighborhoods, two all-black enclaves located to the south and southeast of the large central neighborhood (see Figure 1). ${ }^{13}$

Across most of the city, and particularly on the edges of the central African American neighborhood, lines of residential segregation were fairly rigid. Homeowner associations actively enforced restrictive covenants that prohibited white residents from selling their homes to African Americans. Moreover, the housing market in Kansas City was tight due to the lengthy lull in residential construction associated with the Great Depression and World War II. ${ }^{14}$ Nevertheless, during the 1940s, the African American population in Kansas City grew by more than fourteen thousand, with about 90 percent of that growth occurring in the large central neighborhood centered on Eighteenth and Vine. ${ }^{15}$

African Americans were drawn to Kansas City for a variety of reasons, but the most influential pull factor was the job market. Employment opportunities for African Americans in Kansas City expanded dramatically during the 1940s as blacks gained access to jobs in several different sectors from which they had previously been excluded. The number of African Americans working in city services grew by 400 percent during this period and, under pressure from the Kansas City Urban League, exclusionary hiring practices were

${ }^{13}$ US Census Bureau, Sixteenth Census of the United States: 1940: Population and Housing: Statistics for Census Tracts, Kansas City, Missouri (Washington, DC: Government Printing Office, 1943), Table 1: Kansas City and Adjacent Area, Population by Race and Nativity, and Occupied Dwelling Units, by Census Tracts, 4.

${ }^{14}$ Sherry Lamb Schirmer, A City Divided: The Racial Landscape of Kansas City, 19001960 (Columbia: University of Missouri Press, 2002), 100-107; Keith Fox Gotham, Race, Real Estate, and Uneven Development: The Kansas City Experience, 1900-2000 (Albany: University of New York Press, 2002), 23-44; William S. Worley, J. C. Nichols and the Shaping of Kansas City: Innovation in Planned Residential Communities (Columbia: University of Missouri Press, 1990), 145-178; G. S. Griffin, Racism in Kansas City: A Short History (Traverse City, MI: Chandler Lake Books, 2015), 49-69; and Kenneth T. Jackson, Crabgrass Frontier: The Suburbanization of the United States (New York: Oxford University Press, 1985).

${ }^{15}$ US Census Bureau, Census Tracts: Kansas City, Missouri-Kansas SMSA, 1950 (Washington, DC: Government Printing Office, 1953), Table 1: Kansas City and Adjacent Area, Characteristics of the Population, by Census Tracts, 7-13. 


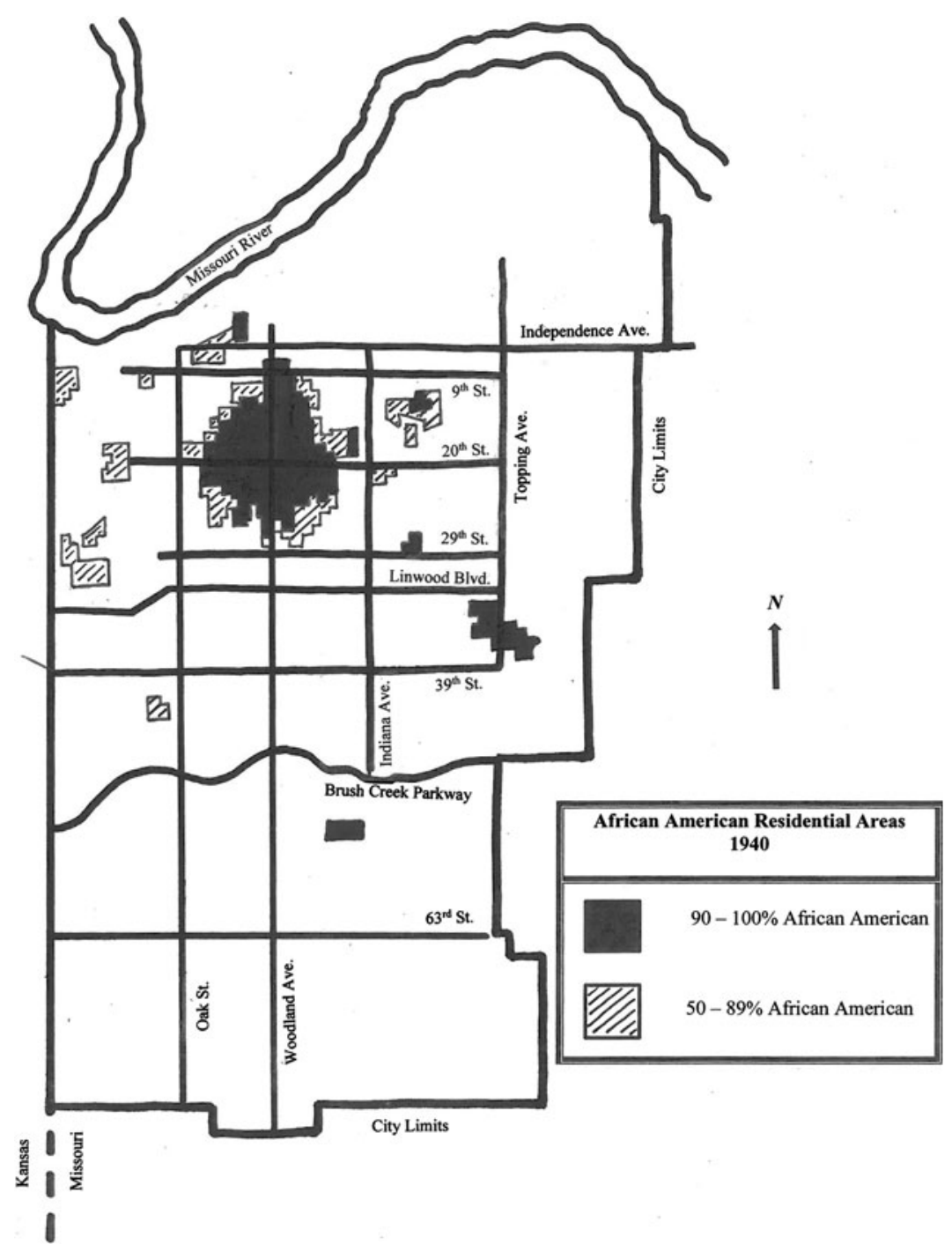

Figure 1. Map of African American residential areas in 1940. ("Negro Residential Areas, 1940," City Planning Office, Kansas City, MO)

dismantled in jobs ranging from meat-packing to gas meter reading. By far the most significant gains in employment for African Americans in the 1940s were in the booming defense industries. Unprecedented job opportunities opened up through a combination of mass rallies and direct action by Kansas City African Americans and President Roosevelt's executive order prohibiting employment discrimination 
by defense contractors. ${ }^{16}$ By the end of the war, more than 12,700 African Americans were employed in defense plants in Kansas City, many of whom were recent migrants with elementary school-age children.

As thousands of African Americans moved into the city in the 1940s, population pressure in the established black residential areas increased significantly. Despite violence, threats, and intimidation, the first black families moved onto city blocks in the Mount Hope and Santa Fe neighborhoods located on the south and southeastern edges of the central neighborhood - areas that had previously been exclusively white. ${ }^{17}$ As the incremental process of city blocks transitioning from white occupancy to black gained momentum, the resolve of some white homeowners to maintain their neighborhood's racially homogeneous composition frayed and restrictive covenants proved to be clumsy legal tools that were not entirely effective in preserving residential segregation patterns. ${ }^{18}$ For a short time, neighborhoods in this southeastern corridor were racially mixed, but such conditions were unstable and temporary. The expansion of the central black neighborhood to the southeast, a pattern first established during the war years, began to transform the racial geography of the city.

In the late 1940s and throughout the 1950s, the process of residential transition accelerated with the continued in-migration of African Americans to Kansas City and the growing exodus of whites to the fringes of the city and the nascent suburbs. The African American population in Kansas City grew by almost ten thousand during the 1950s, and the central black residential district steadily expanded to the southeast (see Figure 2). ${ }^{19}$

Neighborhood transition proceeded so rapidly in the late 1940s and early 1950s that one African American real estate agent, Fred Curls, claimed that "it didn't take much talent real-estate wise; you just had to be a good order taker." ${ }^{20}$ By the early 1950s, white residents routinely violated restrictive covenants, which were no longer legally enforceable following the Supreme Court's 1948 decision in Shelley

${ }^{16}$ Schirmer, A City Divided, 166-76, 180-88, 222. Guichard Parris and Lester Brooks, Blacks in the City: A History of the National Urban League (Boston: Little, Brown, 1971), 256-60, 307-308, 367, 370; Nancy J. Weiss, The National Urban League, 1910-1940 (New York: Oxford University Press, 1974), 163-64, 184, 189; and Edward Stanley, ed., National Urban League 40th Anniversary Year Book, 1950 (New York: National Urban League, 1951), 76-77.

${ }^{17}$ Schirmer, A City Divided, 220-26; Griffin, Racism in Kansas City, 49-69; and Gotham, Race, Real Estate, and Uneven Development, 66-68.

${ }^{18}$ Gotham, Race, Real Estate, and Uneven Development, 23-44.

${ }^{19}$ US Census Bureau, Census Tracts: Kansas City, MO-KS SMSA 1950, 7-13.

${ }^{20}$ As quoted in Schirmer, A City Divided, 226. 


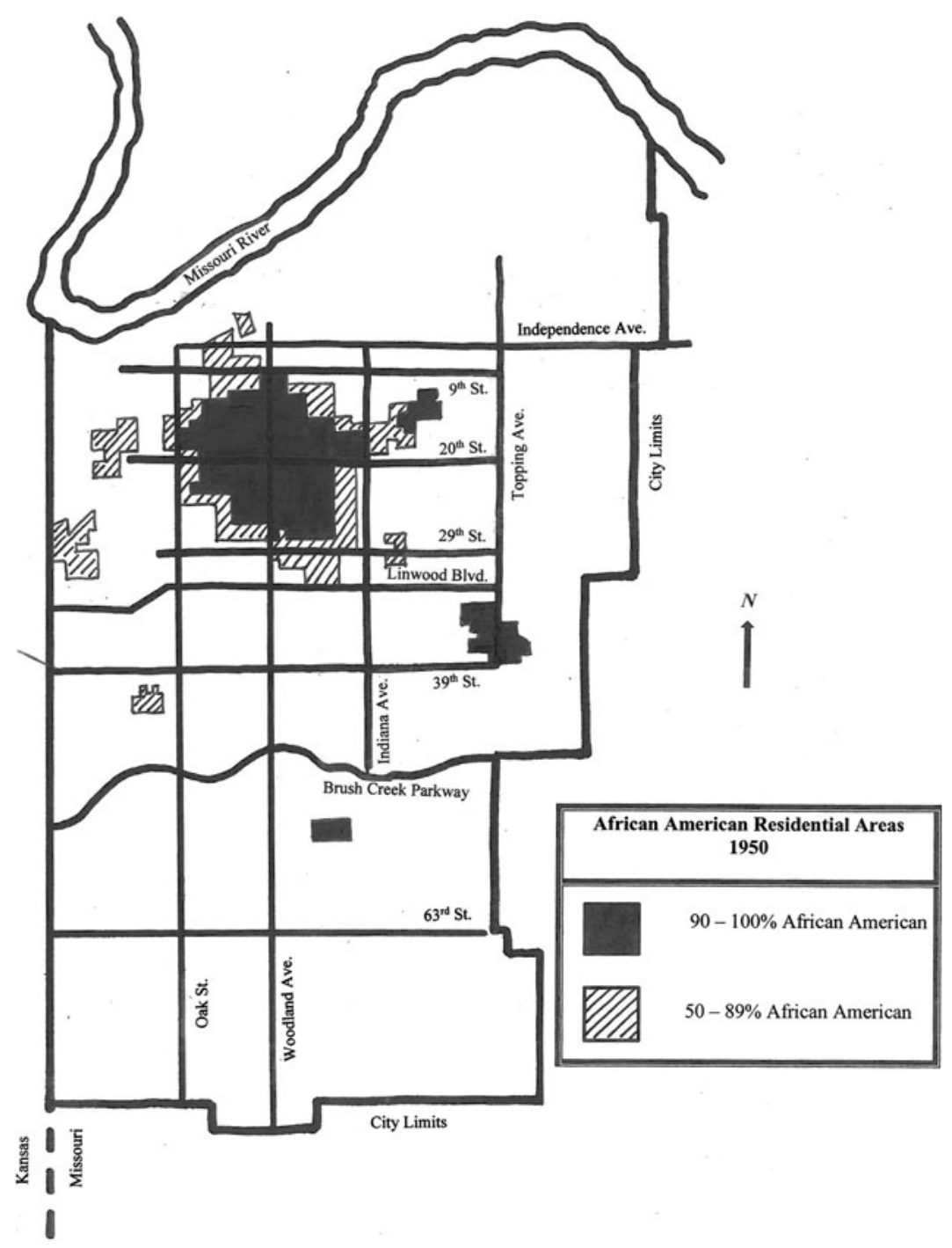

Figure 2. Map of African American residential areas in 1950. ("Negro Residential Areas, 1950," City Planning Office, Kansas City, MO)

v. Kraemer, and sold their homes to African American families. ${ }^{21}$ Black and white real estate agents acted in concert to speed the transition process along by regularly engaging in blockbusting and steering

${ }^{21}$ Shelley v. Kraemer, 334 U.S. 1 (1948). 
African American buyers into the southeast corridor. In some instances, the white real estate agents representing white sellers colluded with black real estate agents representing African American buyers to facilitate the rapid transition of entire city blocks. ${ }^{22}$ These dramatic demographic shifts in the neighborhoods on the fringes of the large central black neighborhood had a profound impact on the management of the city's segregated public school system.

\section{The Kansas City Public Schools}

In accord with the Missouri state constitution, the public schools in Kansas City were racially segregated. ${ }^{23}$ Schools in Missouri adhered strictly to the mandate of separate but equal, but in that context Missouri was somewhat of a leader among states requiring segregated education. Whereas state funding for separate schools was grossly uneven across the Deep South, at least until the Supreme Court's 1950 Sweatt $v$. Painter decision, the state funding formula used in Missouri financed schools for white and African American children equally. Educational funds in Missouri were allocated without bias, with each school district receiving the same amount of state funds per pupil, regardless of race or ethnicity. Furthermore, the state of Missouri required school districts to pay black and white teachers according to the same salary scale and threatened to withhold state funding from those districts that did not comply. Moreover, state requirements regarding the school term length were the same for black and white students in Missouri. Simply put, the structure of segregated education in Missouri was quite different from Mississippi, where the state appropriated five times as much money for each white student, and African American teachers on average earned one-third of what their white counterparts were paid. ${ }^{24}$

\footnotetext{
${ }^{22}$ Schirmer, A City Divided, 220-26; and Gotham, Race, Real Estate, and Uneven Development, 104-13.

${ }^{23}$ Mo. Const. of 1949, art IX, $\ 1($ a); and Mo. Rev. Stat. $\$ 163.130$ (1949).

${ }^{24}$ Gunnar Myrdal, An American Dilemma: The Negro Problem and Modern Democracy (New York, Harper \& Row, 1962), 338-39; Department of Education, 100th Report of the Public Schools of the State of Missouri for the School Year Ending June 30, 1949 (Jefferson City, MO: Mid-State Printing, 1949), 281, 305, 333, 361, 382; Alethea H. Washington, "The Availability of Education for Negroes in the Elementary School," Journal of Negro Education 16, no. 3 (July 1947), 439-49; Charles H. Thompson, "The Availability of Education in the Negro Separate School," Journal of Negro Education 16, no. 3 (July 1947), 263-68; Charles C. Bolton, "The Last Holdout: Mississippi and the Brown Decision," in With All Deliberate Speed: Implementing Brown v. Board of Education, ed. Brian Daugherity and Charles C. Bolton (Fayetteville: University of Arkansas Press, 2008); and Arthur Benson, "School Segregation and Desegregation in Kansas City, Missouri" (unpublished paper, Spring 1995), Arthur Benson Papers,
} 
Within the broad parameters the state government established, the quality of segregated education in Missouri varied from one district to the next. Smaller towns and rural districts had particular difficulty providing a quality kindergarten-through-high school education to African American students due to the challenges of duplicating the teaching force, facilities, materials, and curriculum required in order to adequately serve relatively small numbers of black students. Indeed, the great majority of smaller districts simply could not afford to provide an education for African American students beyond eighth grade within the local district. ${ }^{25}$ Even so, school officials in Missouri complied with the state mandates. For example, Grundy County, located in the north-central section of the state, provided daily taxi service for its lone African American student to attend high school in a town fifty miles away, at an annual cost to the county of more than $\$ 1,200 .{ }^{26}$ In Missouri, as was true for other states with segregated school systems, larger school districts were clearly more able to provide a quality education for African American students, particularly beyond the elementary grades.

In the state's larger cities, including Kansas City, school districts offered a comprehensive curriculum through high school for black and white students alike which, although separate, was comparable in most respects. In Kansas City, black and white students studied the same curriculum and used the same textbooks, both of which were developed and adopted by biracial committees. School facilities in the district were comparable regardless of race, and the most modern school in the district was Lincoln High School, an African American school completed in the 1930s to replace the old Lincoln High School. ${ }^{27}$ Having the advantage of a larger pool of college-educated applicants, the teaching staffs in Kansas City's segregated system were also equally well qualified. Although the teaching faculties were segregated

State Historical Society of Missouri Research Center-Kansas City, University of Missouri-Kansas City.

${ }^{25}$ John L. Rury and Shirley A. Hill, The African American Struggle for Secondary Schooling, 1940-1980: Closing the Graduation Gap (New York: Teachers College Press, 2012), 25-38.

${ }^{26}$ George D. Brantley, "The Present Status of Integration in the Public Schools of Missouri," Journal of Negro Education 24, no. 3 (Summer 1955), 293-309; Albert P. Marshall, "Racial Integration in Education in Missouri," Journal of Negro Education 25, no. 3 (Summer 1956), 289-98; and Monroe Billington, "Public School Integration in Missouri, 1954-1964," Journal of Negro Education 33, no. 3 (July 1966), 252-62.

${ }^{27}$ Lincoln High School, Histories of Individual Schools Files, KCMSD Archives; and "Lincoln College Prep History," in Lincoln College Preparatory Academy, http://www.kcpublicschools.org/Page/1016. 
by race, every teacher in the district held a college degree. The inequities in Kansas City's public school system were less glaring than in many other segregated school districts. African American teachers on average had fewer years of teaching experience and fewer credit hours of post-baccalaureate education. Consequently, according to the school district's salary scale, the average black teacher earned a few hundred dollars less each year than the average white teacher. They also had slightly larger class sizes. African American teachers worked in classrooms with an average of two more students than their white counterparts. Furthermore, the school district provided no transportation for students of either race, which had a disproportionately negative impact on African American students. Because the attendance zones for black schools were much larger than those for whites, some African American students had a significantly longer walk to school than their white peers. Finally, although every segregated black school had an African American teaching corps and an African American principal, the central administration of Kansas City Public Schools included no blacks. ${ }^{28}$

In 1940, Kansas City's public school system comprised more than sixty schools for white students and twelve for blacks. African American children living in the large central neighborhood received their elementary education at one of the six grade schools in the immediate area. For anyone with sufficient background in American history and culture, the names of those schools left little doubt as to the racial identity of their student bodies. In the central African American neighborhood, Kansas City's segregated black elementary schools honored Crispus Attucks, a free black killed in the Boston Massacre; Blanche Bruce, the first African American elected to a full term in the US Senate; three prominent abolitionists, Wendell Phillips, William Lloyd Garrison, and Charles Sumner; and W. W. Yates, who had served as the principal of Kansas City's black high school for almost thirty years. The core neighborhood was also home to both of the city's black secondary schools: R. T. Coles Junior High, named for a longtime teacher and administrator in Kansas City's segregated black schools, and, of course, Lincoln High School. African American children living to the south and southeast of the large central neighborhood attended elementary schools that honored great black poets Phillis Wheatley and Paul Dunbar. On the city's west side, Frederick Douglass Elementary School housed most of the African American youngsters,

${ }^{28}$ 100th Report of the Public Schools of the State of Missouri, 281, 305, 333, 361, 382; Office of the Superintendent, Statistical Data for the Public Schools of Kansas City, Missouri, 1946-1947, KCMSD Archives; and State ex rel. Hobby et al. v. Disman et al., 250 S.W.2d 137 (Mo. 1952), 138. 


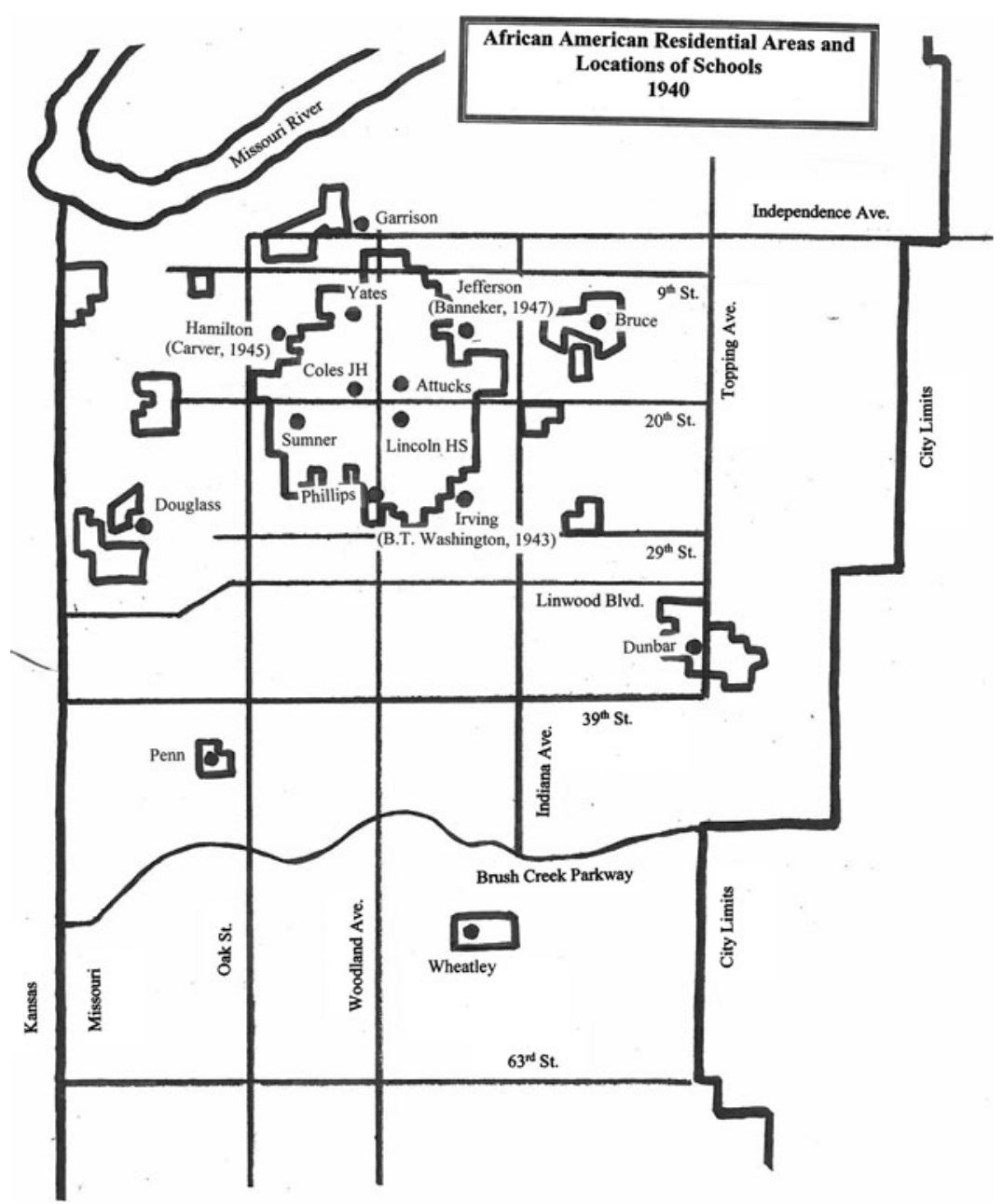

Figure 3. Map of African American residential areas and school locations in 1940.

while others attended the small William Penn Elementary School, a facility originally operated as part of the Westport School District and annexed by Kansas City in 1899 (see Figure 3). ${ }^{29}$

In 1940, these twelve schools were adequate for serving the city's black school-age population. However, as was true in a number of

${ }^{29}$ For further details, see the individual school files for the following schools: Attucks, Bruce, Coles, Douglass, Dunbar, Garrison, Lincoln, Penn, Phillips, Sumner, Wheatley, and Yates, Histories of Individual Schools, KCMSD Archives. 
cities, the African American population in Kansas City had been growing steadily since the turn of the century. The city's changing demographics produced extreme population pressure in certain sections of the city, particularly the segregated black areas. ${ }^{30}$ Moreover, rapid change in the racial composition of neighborhoods undergoing the transition from white to African American carried serious implications for managing the school district in terms of crowding in the schools. As African Americans migrated to Kansas City during the 1940s and early 1950 s, the school district was compelled on four occasions to address looming crises involving severe overcrowding in the segregated black schools.

\section{Race, Demographic Change, and School Conversions}

During the 1940s, Kansas City's African American population grew by about 33 percent to more than fifty-five thousand, and the school-age population grew accordingly. ${ }^{31}$ Most of these new residents settled in the large established black neighborhood bordering the downtown area, and population pressure in the area reached critical proportions. As a considerable number of the new migrants were young families, the growth of the city's African American population was particularly evident in the segregated black elementary schools, which steadily grew more crowded. Furthermore, the increase in African Americans breached the rigid lines of residential segregation that had defined the limits of the core neighborhood, and the black residential section slowly expanded into previously white areas. The introduction of African American families into the surrounding neighborhoods frequently prompted additional white families to move away from the area. Consequently, in the early 1940s, as the black residential area expanded and the African American school-age population grew, enrollment in some of the segregated white schools bordering the large central black area began to decline.

By the close of the 1942 school year, it was readily apparent that the existing schools for African Americans were insufficient for the swelling student population, and school officials began to consider converting a white elementary school for use by black students.

\footnotetext{
${ }^{30}$ For developments in other cities, see Allan H. Spear, Black Chicago: The Making of a Negro Ghetto, 1890-1920 (Chicago: University of Chicago Press, 1967), 44-54, 8387; Vincent P. Franklin, The Education of Black Philadelphia: The Social and Educational History of a Minority Community, 1900-1950 (Philadelphia: University of Pennsylvania Press, 1979), 48-59, 71-86, 128-50; Leiberson, A Piece of the Pie, Taeuber and Taeuber, Negroes in Cities; and Lemann, The Promised Land.

${ }^{31}$ US Census Bureau, Census Tracts: Kansas City, Missouri-Kansas SMSA, 1950, 7-13.
} 
Such changes were not uncommon in Kansas City. On previous occasions, school officials had responded to population changes and crowding in the schools designated for African American students by converting white schools to black schools. The principal difficulty in converting a school was determining which white school to convert. The process was typically accompanied by opposition from the white community, especially from residents living in transitional neighborhoods whose children attended the schools being considered for conversion. White opposition tended to be relatively mild, however, because the school board consistently delayed converting a school until it was absolutely clear that the neighborhood transition process from white to black in a particular area was irreversible and that the surrounding neighborhood appeared destined to become exclusively African American. By delaying a school's conversion, the school board ensured that a relatively small number of whites would be inconvenienced, while African American schoolchildren endured months of gross overcrowding in their schools without relief. A second motive in delaying decisions to convert a particular school lay in the school board's interest in protecting itself from accusations that its action had initiated or anticipated a demographic shift that was not yet underway. ${ }^{32}$ Timing, then, was crucial in stymieing protests from white residents, and in 1942 the school board began deliberations regarding which school to convert to accommodate the rising numbers of African American elementary students while displacing the fewest number of whites.

In early June 1942, after conducting a detailed study of the residences of white and black students on the fringes of the core black neighborhood, school officials announced that Washington Irving Elementary School would be converted to use for African American students. Despite protests from the parents of children attending Washington Irving, the school board's choice was relatively simple. Located on the southern edge of the core African American area, Washington Irving had previously housed as many as twelve hundred white students, but by the early 1940s, just over two hundred students attended. The area around Washington Irving was clearly in the process of shifting from white to black. School board members maintained that their decision to convert the school to African American use was made only after the study revealed "an overwhelming preponderance

32 "Irving Area Study," Washington Irving School File, KCMSD Archives; and Kansas City (MO) School District, "A Survey of Circumstances Relevant to the Current and Projected Increases in School Membership in Booker T. Washington Elementary School," Building Needs, Bond Issues, School Building, 1952-1954, Booker T. Washington School File, KCMSD Archives (hereafter cited as Building Needs). 
of colored children" living in the neighborhood near the school. ${ }^{33}$ Having determined to convert Washington Irving, the Board of Education, as if to clarify that the school would indeed be for black use, took the symbolic step of changing the school's name as well. When the doors opened for the 1943 school year, the African American youngsters who attended the school entered Booker T. Washington Elementary School (see Figure 3). ${ }^{34}$ Any discussion among school board members regarding the name change took place outside of the board meeting, and there is no evidence that the board members consulted anyone from the African American community before announcing the name change. Although it is unclear which board member suggested renaming the school for Booker T. Washington, the recommendation was approved without dissent. As had been the case with previous school conversions and name changes, the school board members concluded unanimously that a more appropriately black name was only logical for a school that would serve African American children.

The conversion of Washington Irving to Booker T. Washington temporarily relieved the crowding in the segregated schools serving Kansas City's central African American neighborhood. Yet within two years, school district officials were again compelled to consider converting a facility from white to black. Between 1942 and 1945, African American elementary school enrollment grew by nearly seven hundred students. By 1945, several of the core area schools were operating above capacity and Booker T. Washington was dangerously overcrowded. Indeed, the school, which had been converted only three years earlier, housed as many as fifty-seven students in some classrooms. ${ }^{35}$ Concluding that "some immediate relief is necessary," Superintendent of Schools Herold Hunt recommended in February 1945 that Alexander Hamilton Elementary, a school for special needs white students located in an area undergoing racial transition on the northern edge of the central black neighborhood, be converted to a segregated African American elementary school. ${ }^{36}$ The conversion of Hamilton Elementary was concluded with relative ease because the school did not serve a white neighborhood, but rather

${ }^{33}$ Minutes of the Board of Education, June 4, 1942, Doc. No. 191579, SC23 Kansas City (Mo.) School District Records, Missouri Valley Special Collections, Kansas City (MO) Public Library (hereafter cited as BOE Meeting Minutes); and "Irving Area Study."

${ }^{34}$ BOE Meeting Minutes, June 4, 1942, Doc. No. 191503.

${ }^{35}$ Roscoe V. Shores to Herold C. Hunt, Feb. 23, 1945, filed with BOE Meeting Minutes, March 1, 1945, Doc. No. 199674.

${ }^{36}$ Herold C. Hunt to the Board of Education, Feb. 23, 1945, filed with BOE Meeting Minutes, March 1, 1945, Doc. No. 199674. 
drew special education students from across a much larger section of the city. Special education classrooms at three nearby schools absorbed the eighty-nine displaced white students, and the building was made available to African American students. Adjustments to the attendance zone boundaries for African American elementary schools relieved the acute crowding at Booker T. Washington. Once again, however, the school board determined that a school that served African American students required a more racially appropriate name. Accordingly, the Board of Education renamed the school George Washington Carver Elementary in March 1945 (see Figure 3). ${ }^{37}$ Following the same pattern as previous school conversions, the name change was not discussed in the school board's public meetings, there is no indication that board members consulted with anyone from the African American community, and the resolution changing the name to Carver Elementary was approved without dissent. When the school was made available to African American students the following September, nearly five hundred enrolled. ${ }^{38}$

The opening of Carver Elementary relieved the immediate problem of crowding in the black elementary schools. The migration of African Americans to Kansas City, however, continued unabated, and within two years the school district again confronted a critical shortage of classroom space in the central black neighborhood. Four elementary schools in the core area, Yates, Attucks, Phillips, and Booker T. Washington, were again operating above capacity, and all four were projected to enroll even more students the following year. The white school selected for conversion in 1947 was Thomas Jefferson Elementary, located on the northeastern fringe of the central black residential area. Converting Jefferson Elementary to a segregated African American school would allow the school district to relieve the severe crowding at Yates and Attucks, the two nearest black schools. Acting Superintendent Roscoe Shores recommended that 120 students from Attucks and 188 students from Yates be transferred to Jefferson Elementary. Moreover, Shores maintained that by converting Jefferson Elementary the school district would be responding to demographic shifts that had already largely run their course. He noted that "now Negroes are on all four sides of the building" and that "for the past few years, the people living in the Jefferson district have anticipated its becoming a Negro school." Shores expected little opposition from whites remaining in the area, concluding that

\footnotetext{
${ }^{37}$ BOE Meeting Minutes, March 1, 1945, Doc. No. 199674.

${ }^{38}$ Roscoe V. Shores to Board of Education, Aug. 1, 1947, filed with BOE Meeting Minutes, Aug. 7, 1947, Doc. No. 218049.
} 
"most of the white residents have become reconciled to the inevitability of this [conversion to use for African American students]." 39

Once again, the Board of Education decided that a name change was in order. When the building opened to black students in the fall of 1947, it was no longer Thomas Jefferson Elementary School but rather Benjamin Banneker Elementary School (see Figure 3). In this case, Shores apparently urged that the school district honor Banneker. Shores's report on the situation and his recommendation to convert Jefferson to use for black students included a curious eulogy of sorts, listing a number of Banneker's accomplishments as an astronomer, surveyor, and inventor, and concluding that "his genius was accepted as early proof of the intellectual ability of Negroes."

Having converted three schools to use for black students in a span of just five years, Kansas City Public Schools again reached a temporary parity with the steadily rising number of African American students. Another five years passed before the school board contemplated converting a school from white to black use. However, during those five years, the African American population in the city continued to grow steadily, and the elementary schools in the central black neighborhood grew increasingly crowded. By the time the school board considered another conversion in 1952, the acute crowding in the schools serving the black core had reached unprecedented levels. Although school officials were well aware of the serious overcrowding at Booker T. Washington since at least the 1950-51 school year, they shrank from the idea of converting another school from white use to black because there was no simple solution-no neighboring white school that was grossly under capacity. Essentially, between 1950 and 1952, school officials concluded it was preferable to tolerate extensive overcrowding in the black schools-Booker T. Washington, in particular - than to risk the wrath of whites living on the fringes of the central black residential area whose neighborhood school could be converted to use by African American students. Indeed, the reluctance of school officials to address the situation at Booker T. Washington is clear in that the school board and superintendent did not direct the district's research department to undertake a study of population trends in the area until after the 1952-53 school year started. ${ }^{41}$

Since its conversion to a segregated black school in 1942, Booker T. Washington Elementary had consistently operated at or above capacity. Built for about eight hundred students, the school housed

\footnotetext{
${ }^{39}$ Shores to Board of Education, Aug. 1, 1947.

${ }^{40}$ Shores to Board of Education, Aug. 1, 1947.

${ }^{41}$ Building Needs.
} 


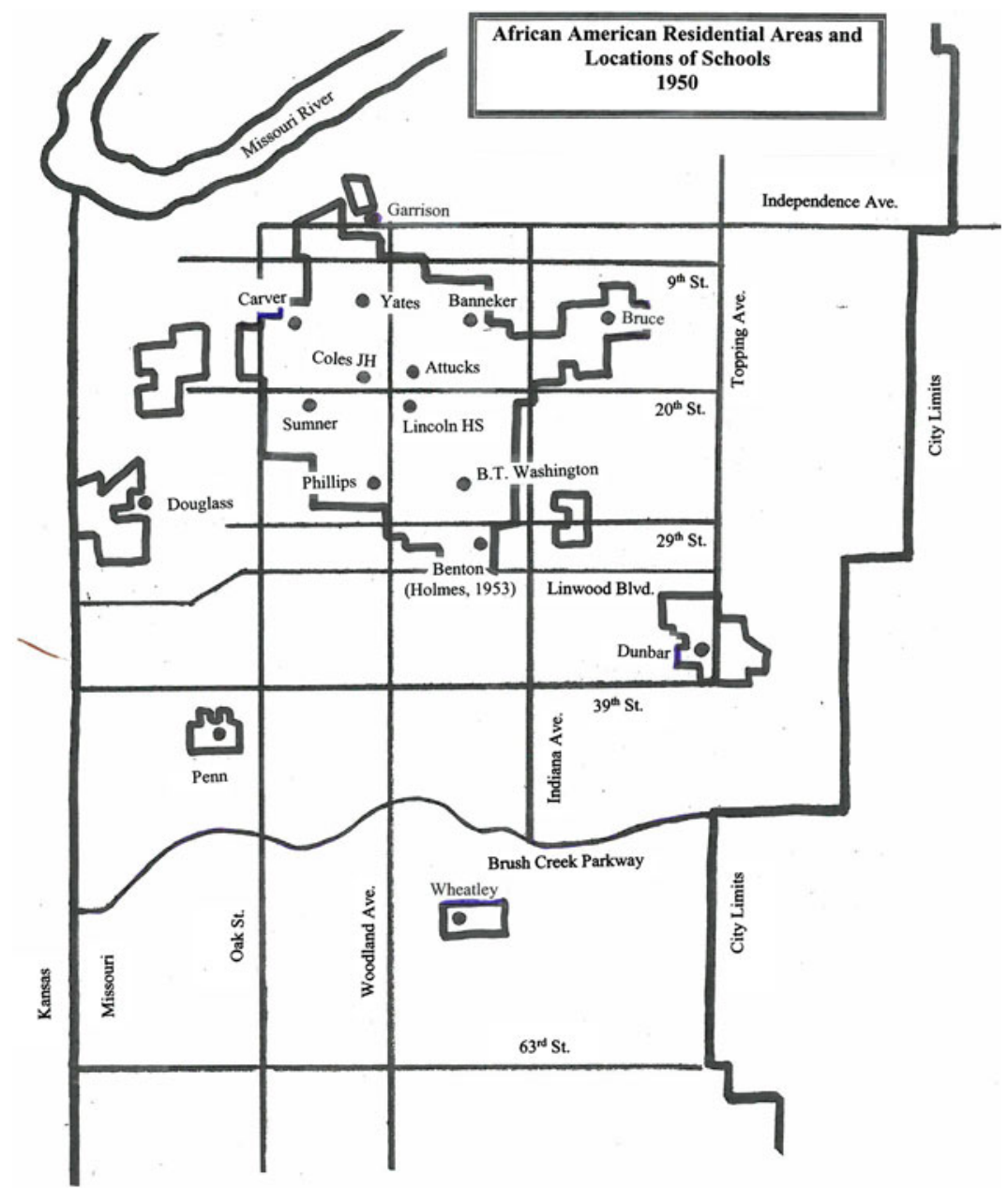

Figure 4. Map of African American residential areas and locations of schools in 1950.

almost twelve hundred students by 1950, more than thirteen hundred in 1951, and at the start of the 1952 school year enrolled more than fifteen hundred black youngsters. ${ }^{42}$ In order to accommodate the growing enrollment, the assistant superintendent for buildings and grounds, G. Dewey Smith, observed, "Every practical space has been converted to classroom use." In fact, the school district had divided the

${ }^{42}$ Disman et al, 250 S.W. 2d at 140; Building Needs, 108; and "Most Pupils Since 1932," Kansas City Star, Sept. 6, 1951, 3. 
auditorium at Booker T. Washington into three classrooms, converted the homemaking and industrial arts rooms and two storage rooms in the school's basement to regular classrooms, transported ninety students to Sumner Elementary School, and moved the kindergarten classes to rented rooms a few blocks away in a building that also housed a grocery store, a dance hall, and other businesses. ${ }^{43}$

Determined to pressure the school board to provide some relief for the extraordinary crowding at the school, the parents of Booker T. Washington students organized. In September 1952, a delegation of 150 parents appeared before the Board of Education decrying conditions at the school. Harold Holliday, the city's leading African American attorney, was the spokesperson for the concerned parents. He reminded the school board that overcrowding in the segregated black schools was "the same situation that it has been our unfortunate duty to bring before you on several previous occasions." Holliday described Booker T. Washington Elementary as "an unmitigated firetrap" and argued that "not only are our children being denied adequate facilities for learning, but they are daily placing their very lives in danger." ${ }^{4}$ The situation at Booker T. Washington, Holliday stated, demanded urgent action and he proposed that Thomas Hart Benton Elementary, a nearby white elementary school, be immediately converted to a black school (see Figure 4). The same month, a group of some forty-five parents, under the direction of the school's PTA president, Sidonia Westbrook, began picketing in front of the school district's central offices in downtown Kansas City. The picketing continued for the better part of the next month. ${ }^{45}$ In October, some three hundred members of a Booker T. Washington citizens' council, led by chairman Thomas Webster, met in the school's gymnasium to plan additional action. At that meeting, the parents voted overwhelmingly in favor of a school boycott, and for the next two weeks, fewer than 300 of the 1,536 students enrolled at Booker T. Washington attended classes. ${ }^{46}$

Despite protests by black community members, school district officials refused to consider converting a white school during the 1952-53 school year. Arguing that making such a modification during the winter holiday break would produce chaos and result in a situation

\footnotetext{
${ }^{43}$ Building Needs, 106, 126, 163-64, 168-70; and "In Basements and Corridors: An Editorial," Kansas City Star, May 23, 1951, 1.

${ }^{44}$ BOE Meeting Minutes, Sept. 18, 1952, Doc. No. 235851. See also "Ask School Shift," Kansas City Times, Sept. 19, 1952, 3.

45 "Pickets at School," Kansas City Star, Sept. 30, 1952, 4; "Pickets at School Board," Kansas City Star, Oct. 28, 1952, 2

46"To Boycott a School," Kansas City Times, Oct. 29, 1952, 3.
} 
where "educationally, everyone would lose," the superintendent promised that a change would be made in time for the start of school the following September. ${ }^{47}$ The school board responded by directing the district's administration to conduct a study of population trends in the area around Booker T. Washington and make recommendations for converting a white school. ${ }^{48}$

By December 1952, the school board narrowed its choices to Benton Elementary and Robert Yeager Elementary, both of which bordered on the expanding black neighborhood and were experiencing declining enrollment as white families moved away. ${ }^{49}$ Although the neighborhoods around both schools were clearly in transition from white to black, substantial numbers of white residents remained in each neighborhood. Whites accounted for 41.5 percent of the population within the Benton Elementary zone and 56 percent of the population within the Yeager zone. ${ }^{50}$ The significant number of whites remaining in these areas presented the school district with a vexing problem. In previous cases where a school had been converted from white use to black, the school district had essentially reacted to demographic shifts that had already largely run their course. Such was not the case at Benton and Yeager. Consequently, the school board was confronted with the unpleasant prospect of spurring additional white flight from a neighborhood by converting the local neighborhood school to use by black students. Historically, the school district had attempted to avoid such situations by delaying the conversion of a school from white to black use until the affected neighborhood had largely turned black. School officials were not afforded that luxury in the Booker T. Washington situation. Crowding at the school was extreme and could not be ignored indefinitely. Moreover, the parents of the school's students were well organized and aggressively pressing for a solution. Indeed, one month after the school boycott, a group of parents moved to exert additional pressure on the school district.

On December 11, 1952, fourteen parents of Booker T. Washington students filed a lawsuit against the school district in Jackson County Circuit Court seeking a court order to immediately convert a neighboring white school to use by African American students. The parents'

47 "To Boycott a School."

${ }^{48}$ Building Needs, 112-30, 168; "The City's Most Crowded School," Kansas City Star, Oct. 25, 1952, 14; "On with School Protest," Kansas City Star, Oct. 29, 1952, 3; "School Protest," Kansas City Star, Nov. 9, 1952, 3A; "Suit over School," Kansas City Star, Dec. 11, 1952, 12; "To Boycott a School": "End School Boycott," Kansas City Times, Nov. 12, 1952, 3; and BOE Meeting Minutes, Dec. 4, 1952, Doc. No. 236192.

${ }^{49}$ Building Needs, 111-30; and BOE Meeting Minutes, Oct. 16, 1952, Doc. No. 236056.

${ }^{50}$ Building Needs, 112-30, 168. 
complaint enumerated the many "intolerable and unbearable conditions" at the school and accentuated the health and safety hazards associated with a school operating at nearly twice its recommended capacity. The suit also alluded to a possible course of relief, noting that enrollment at the nearest segregated white school, Benton Elementary, was less than 50 percent of capacity and that five classrooms at the school were entirely vacant. ${ }^{51}$

Judge Elmo B. Hunter, the circuit court's head of assignments, effectively nullified the immediate relief the parents were seeking in their legal assault against the school district. Hunter denied the request for an expedited hearing and assigned the case to Judge Duval P. Strother, with proceedings to begin in January. ${ }^{52}$ By scheduling the hearing for January, Judge Hunter extinguished any possibility that a white school could be converted to African American use during the winter holiday. The parents' desire for immediate relief at the school was further stymied by Judge Strother. Although he heard arguments in mid-January, Strother did not rule on the issues until August, at which time he simply affirmed the course of action the school district had approved months earlier. ${ }^{53}$

The parents' complaint was further undermined by the school board that same January. At the superintendent's recommendation, the school board approved a half-day schedule for Booker T. Washington in which half of the student body reported for classes in the morning and the other half in the afternoon. The arrangement effectively reduced the school's enrollment at any given time by 50 percent, returned the school to operating within its capacity, and allowed the kindergarten classes to return to Booker T. Washington. ${ }^{54}$

However, the half-day schedule clearly created additional hardships for parents in terms of getting children to and from school at unusual times and the need for many to arrange for child care outside of school. Moreover, by essentially cutting the school day in half, the arrangement plainly harmed the children. Indeed, the split schedule openly violated the state requirement that students receive six hours of instructional time each school day. In mid-January, when Holliday and Lewis Clymer, the attorneys for the African American plaintiffs, presented these arguments in Judge Strother's courtroom, they were again were rebuffed. The judge refused to issue an order enjoining

\footnotetext{
${ }^{51}$ Opinion and Judgment, Pugh, et al. v. Joslyn et al., Docket No. 563,805, unreported opinion (Circuit Court of Jackson County, Aug. 3, 1953) in Booker T. Washington School File, KCMSD Archives; and "Suit over School."

52 "Suit over School."

${ }^{53}$ Pugh v. Joslyn, unreported opinion, Aug. 3, 1953.

${ }^{54}$ BOE Meeting Minutes, Jan. 8, 1953, Doc. No. 236285.
} 
the school district from adopting the half-day schedule as a temporary expedient to relieving the school's acute overcrowding. ${ }^{55}$

Having been granted a reprieve of sorts by the Jackson County Circuit Court judges, and having created a stop-gap solution to the excessive crowding at Booker T. Washington, the school board focused its attention in 1953 on converting a school to African American use for the coming school year. Following the announcement in December that the school board had narrowed its choices for conversion to Benton and Yeager, members of the neighborhood associations and PTAs for both schools regularly addressed the school board. ${ }^{56}$ By late January, school board meetings were drawing crowds in excess of two hundred, as concerned parents and neighbors jammed the gallery and the hallway outside the board room. At each meeting, the delegations representing the two white schools presented similar arguments against converting Benton or Yeager to use by African American children. Neither neighborhood, they maintained, had become majority black. Moreover, speaking for the Benton PTA, Robert Holder argued that, should the school board opt to convert a white school, the result would be "a vacuum with a Negro school at the center." To Holder and others living in the area, such a change would inevitably precipitate "attendant changes of neighborhood and adjustment of property values." 57

Concerned citizens from the Benton, Yeager, and Booker T. Washington neighborhoods were not the only groups attending school board meetings during the early months of 1953. Many white Kansas Citians perceived developments in the Booker T. Washington situation as an eerie harbinger of what could happen in their own neighborhoods. Between January and March 1953, eighteen different neighborhood councils, homeowners' associations, and community groups appeared at Board of Education meetings urging the school board to reconsider its decision to convert a school to black use. ${ }^{58}$ The majority of these groups represented areas of the city located south of Benton and were home to some sixty thousand residents, about one-eighth of Kansas City's population. Their interest in objecting to converting Benton or Yeager lay largely in the opportunity

${ }^{55}$ Pugh v. Joslyn, unreported opinion, Aug. 3, 1953.

${ }^{56}$ BOE Meeting Minutes, Jan. 22, 1953, Doc. No. 236313; BOE Meeting Minutes, Feb. 5, 1953, Doc. No. 236370; and BOE Meeting Minutes, March 5, 1953, Doc. No. 236422.

${ }^{57}$ BOE Meeting Minutes, Jan. 22, 1953, Doc. No. 236313.

${ }^{58}$ BOE Meeting Minutes, Jan. 22, 1953, Doc. Nos. 236313, 236314; BOE Meeting Minutes, Feb. 5, 1953, Doc. Nos. 236270, 236271; and BOE Meeting Minutes March 5, 1953, Doc. No. 236422. 
presented to arrest, or at least slow, the ongoing expansion of the large central African American neighborhood to the south and southeast, and thereby spare their own neighborhoods from a similar transition. Thus, for thousands of Kansas Citians, who typically were oblivious to conditions at schools other than those their children attended, the Booker T. Washington situation had become an issue of grave importance.

Faced with continued pressure from members of the African American community as well as substantial white opposition, including protests from sections of the city far removed from Booker T. Washington, the Board of Education met in mid-March 1953 to choose between Benton and Yeager. After lengthy discussions in executive session, the school board, by a vote of four to two, opted to convert Benton to a segregated black school for the 1953-54 school year. Ever conscious of the potential impact that school conversions might have on the real estate market, school board member John Gregory maintained that "the majority of the citizens in the Benton School neighborhood are Negroes, we are not establishing a trend." 59 Even so, in the months following the school board's announcement, the neighborhood around Benton underwent a remarkable transition. White residents abandoned the neighborhood in droves, and within two years the surrounding area was essentially all black. ${ }^{60}$ What occurred in the Benton area aligns well with Ansley Erickson's observation regarding "the power of schooling to influence housing markets - that educational policies drove housing patterns, not only the reverse." ${ }^{61}$

After announcing the decision to convert Benton, five months passed before the school board turned its attention to naming the city's newest black elementary school. For a time, it appeared that the Board of Education might defer to the suggestion that the name not be changed. A parents' group from Booker T. Washington, whose children would be attending the school, urged that the board retain Benton as the school's name and thereby minimize the confusion of changing schools. In the end, however, that recommendation proved to be inconsistent with the sort of symmetry in school naming that the board preferred. In early August 1953, Benton was renamed D. A. Holmes Elementary School, in honor of the longtime pastor at

\footnotetext{
${ }^{59}$ BOE Meeting Minutes, March 19, 1953, Doc. No. 236462.

60 "Integration Data, Actual Occurrence Compared with Predicted Occurrence," Desegregation Files, KCMSD Archives; "Enrollment by School, 1954-55-1983-84," Desegregation Files, KCMSD Archives; and "White and Negro Memberships, Sept. 16, 1955," Desegregation Files, KCMSD Archives.

${ }^{61}$ Ansley T. Erickson, "Building Inequality: The Spatial Organization of Schooling in Nashville," Tennessee, after Brown," Journal of Urban History 38, no. 2 (March 2012), 250.
} 
Kansas City's Paseo Baptist Church. ${ }^{62}$ Reverend Holmes had been one of the most influential figures in the early civil rights movement in Kansas City. He had spearheaded the effort to integrate the University of Missouri-Columbia campus in 1939, was well known to members of the school board, and had led the campaign pressuring the school district to build a new Lincoln High School during the 1930s. ${ }^{63}$ The conversion of Benton Elementary marked the last time that the school district switched one of its facilities from white use to black. Two years later, in 1955, the school district began its lengthy struggle to desegregate.

On September 9, Kansas City's schools opened for the 1953-54 school year. That morning, 953 African American children entered D. A. Holmes Elementary for the first time and nearly eight hundred other black students reported to Booker T. Washington Elementary. ${ }^{64}$ In spite of lengthy public hearings, the legal campaign, picketing, impassioned letters to the school board, and multiple community council meetings, both schools opened with enrollments that exceeded building capacity. Two weeks later, the crowded situation at D. A. Holmes was compounded by a cruel irony - a fire seriously damaged several classrooms on the third floor and destroyed sections of the roof. Although officials from the fire department ruled that the blaze had begun accidentally in a third-floor coat closet, some neighborhood residents suspected arson. Due to the extensive damage, totaling more than $\$ 50,000$, much of the building was deemed unsafe for students, and the school district was compelled again to resort to a half-day schedule. $^{65}$

\section{Power, Politics and Perspective}

Kansas City's school system in the 1940s and early 1950s presents a vivid illustration of a major problem faced by administrators managing a segregated school district. When considered purely in terms of managing enrollments, the system functioned adequately, provided that the city remained static. However, in a city such as Kansas City, where demographic trends were dynamic and the lines defining the

\footnotetext{
${ }^{62}$ BOE Meeting Minutes, Aug. 6, 1953, Doc. No. 239170.

${ }^{63}$ Biography of Reverend D[aniel] A[rthur] Holmes, CD90, Missouri Valley Special Collections, Kansas City (MO) Public Library.

${ }^{64}$ KCMSD Research Office, "Enrollment 1953-54," Research Files, KCMSD Archives.

${ }^{65}$ Gotham, Race, Real Estate, and Uneven Development, 67; "\$50,000 in Damages at Benton," Kansas City Call, Oct. 2, 1953, 2; "The Mysterious Benton Fire," Kansas City Call, Oct. 2, 1953, 3; and "Fire Guts School Whites Transferred to Negroes," Jet, Oct. 8, 1953, 29.
} 
prevailing patterns of residential segregation were somewhat fluid, the segregated system was an inflexible framework that invariably discriminated against African American children by delaying what otherwise would have been appropriate adjustments necessary to meet the need for additional classrooms in the black residential area. In essence, school officials in Kansas City never embraced the perspective that the Kansas City Ministerial Alliance offered during the Booker T. Washington controversy. The ministers argued that "what little adjustment that will need to be made by the white students in this matter is small compared to the damage that is being done to the Negro students." ${ }^{66}$ On the contrary, the school leaders relied upon the notion that crowding in the black schools could be tolerated until it was readily apparent that an adjacent neighborhood had turned black. At that point, school officials had few reservations about converting a school. However, in instances such as Booker T. Washington in 1952, school officials balked at converting a white school because of the implication that doing so might impact the real estate market and promote white flight. Indeed, it appears there was some truth to that assumption. When the Kansas City schools became desegregated in 1955, only 6 percent of the enrollment at D. A. Holmes Elementary was white-a school which two years earlier had been the segregated white school named Benton. Between 1953 and 1955, hundreds of white families had moved from the neighborhood around the school. The same is true for the neighborhoods served by Yeager Elementary and James M. Greenwood Elementary School, two other segregated white schools on the fringes of the large, core African American residential area. When those schools opened on a desegregated basis in 1955, each had an enrollment that was more than 75 percent African American. ${ }^{67}$

The demographic shifts around D. A. Holmes, Yeager, and Greenwood are significant because they illustrate how white flight out of neighborhoods bordering on the core African American residential area was already well underway prior to the desegregation of the Kansas City schools in 1955. Between the late 1940s and early 1950s, thousands of white families had fled the neighborhoods to the south and southeast of the core black area. Entire neighborhoods were transformed in a few years from all-white to virtually all-black. That process of neighborhood transition continued - and accelerated-with desegregation of the public schools, but it had been ongoing for several years prior.

In light of what happened at D. A. Holmes, it does not seem unreasonable to suggest that a school, being among the most significant

\footnotetext{
66"End School Boycott," Kansas City Times, Nov. 12, 1952, 3.

67 "Enrollment by School," Desegregation Files, KCMSD Archives.
} 
institutions serving a neighborhood, has tremendous symbolic and psychological value, and in part defines the neighborhood. A school served not only as a center for education but also as a focal point in the community's social and economic life. In many neighborhoods, schools offered some of the most highly valued and sought after opportunities for employment. Furthermore, schools were beneficiaries of community investment, both monetarily and in terms of cultural capital and the commitment of time, energy, labor, resources, and expertise on the part of community members. ${ }^{68}$ Moreover, the school provided space for a wide range of community functions, including community group and neighborhood association meetings, recreational activities, and cultural events. ${ }^{69}$ The symbolic character and institutional importance of a school, as well as the great variety of other functions a school provided, arguably carried greater influence in Kansas City because of the racially specific school naming practices in the district. Essentially, the school district insisted that segregated black schools have names that underscored the fact that the school served African American students and, by extension, an African American neighborhood. The name changes, then, effectively were the final symbolic gesture indicating that, in the judgment of the school board, the neighborhood around the school being converted to black use was destined to become predominantly African American. In short, by changing the names of schools converted to use by African American students, the school district had labeled or coded the neighborhood served by the school as "black." Indeed, with the school board's decision to convert Benton, it appears that many whites interpreted the announcement as confirmation that the neighborhood would become part of the growing black residential area. The actions of whites living in the Benton neighborhood underscores the conclusion Karen Benjamin reached in her study of Raleigh, North Carolina,

${ }^{68}$ James D. Anderson, The Education of Blacks in the South, 1862-1935 (Chapel Hill: University of North Carolina Press, 1988), 148-85; V. P. Franklin, "Introduction: Cultural Capital and African American Education," Journal of African American History 87 (Spring 2002), 175-81; Carter Julian Savage, "Cultural Capital and African American Agency: The Economic Struggle for Effective Education for African Americans in Franklin, Tennessee, 1890-1967," Journal of African American History 87 (Spring 2002), 206-35; Peggy B. Gill, "Community, Commitment, and African American Education: The Jackson School of Smith County, Texas, 19251954," Journal of African American History 87 (Spring 2002), 256-68; and Monica A. White, "Paradise Lost? Teachers' Perspectives on the Use of Cultural Capital in the Segregated Schools of New Orleans, Louisiana," Journal of African American History 87 (Spring 2002), 269-81.

${ }^{69}$ See, for example, Joel Spring, The American School, 1642-2000, 5th ed. (New York: McGraw-Hill, 2001), 229-50. 
that "school policy and housing markets shaped each other so extensively that a line cannot be drawn between them."

School board members recognized how choices about converting schools and changing school names carried great influence in the affected neighborhoods, particularly among white residents. Although they certainly relied on advice and recommendations from the school district's central administration, the power to make these types of adjustments to school organization ultimately resided with the six members of the Board of Education. Positions on the school board were elected offices and all six seats on the board were atlarge, rather than seats that represented particular wards. ${ }^{71}$ Because the city's population remained more than three-quarters white until the 1970s, the at-large system virtually assured that all six positions on the Board of Education would be occupied by whites. Moreover, a tacit agreement between the city's Democratic and Republican party leadership further assured that the school board would always comprise three Republican and three Democratic members. For all six positions, candidates that the party's leaders selected ran unopposed in the citywide elections. Year after year, the result of these political arrangements was a school board that was remarkably insular. Throughout the 1940s and 1950s, the Board of Education was consistently made up of well-connected, civic-minded, upper-class whites drawn from the affluent neighborhoods around Country Club Plaza and the southwestern section of the city. School board members moved in the same social circles, embraced similar values, and shared a common commitment to civic service.

Board of Education members also shared a common perspective on how to address demographic change that impacted the school system. Although school officials in Kansas City were proud that their district was, in many respects, a leader in providing separate-but-equal educational opportunities, the chronic crises of overcrowding in the black elementary schools revealed the limits of how far they were willing to go in providing equity. Operating within the constraints of a segregated school system that did not permit reassigning students from grossly overcrowded black schools to nearby white schools with

\footnotetext{
${ }^{70}$ Karen Benjamin, "Suburbanizing Jim Crow: The Impact of School Policy on Residential Segregation in Raleigh," Journal of Urban History 38, no. 2 (March 2012), 227.

${ }^{71}$ In 1970, under pressure from civil rights organizations, the composition of the school board was restructured, with six seats determined by wards and three at-large seats. As a result, the political parties no longer handpicked candidates to run unopposed. Elections were competitive and the composition of the board changed dramatically. Each year since 1970 at least two school board members have been African American. J. Glenn Travis, Historic Report (unpublished paper, 1989), KCMSD Archives.
} 
available classroom space, school officials in Kansas City stalled and adopted the position that providing dangerous, inadequate school conditions for African American children was preferable to inviting protests and criticism from the white community. When faced with the challenge of relieving overcrowding in the African American schools, the district's leadership consistently favored delayed action for months or, in the case of Booker T. Washington, years. Time and again, the civic-minded elites who provided leadership for the school district chose the interests of a relatively small number of white patrons living in neighborhoods undergoing racial transition over the interests of hundreds of African American children who reported daily to schools with facilities that were woefully ill-equipped to provide an adequate education to so many students.

Finally, it is important to recognize the school board's perspective in the process of selecting names for black schools in the segregated system. Today, it is common practice to select names for public buildings, including schools, through a series of open meetings or other processes that actively solicit recommendations from the public. In Kansas City during the 1940s and 1950s, the authority to bestow names on schools resided exclusively with the school board, and board members exercised that authority without consulting anyone except, perhaps, the superintendent of schools. Moreover, during the 1940s and 1950s, Kansas City's school board was composed entirely of upperclass whites from the city's southwestern section, far removed from the black neighborhoods. Consequently, the city's black schools were all named for prominent individuals who were consistent with the upper-class white leadership's notions of appropriate role models for young black students. The fact that there was no debate or discussion about school name changes, and that in every instance the name changes were approved without a single dissenting vote, underscores the ideological agreement among board members that schools attended by African American children should have appropriately black names. The participation of the black community in the process of selecting school names was never solicited, and on those occasions when it was offered, held little sway with the board. When considered in this context, it is thoroughly inconceivable that such a school board would consider opening a Marcus Garvey Elementary School or a W. E. B. Du Bois High School. Despite Du Bois's many accomplishments as a scholar, writer, and intellectual, and the admiration that many in the black community had for figures such as Garvey, both would likely have been regarded as far too controversial for the conservative white civic leaders who sat on the school board.

Choices for school names clearly expressed the school board members' ideological preferences. Their decisions also reflected 
board members' understandings of history as well as their own individual beliefs and values regarding what sort of personal qualities and achievements were worthy of recognition. Abolitionists, a scientist, an astronomer and surveyor, two poets, a black politician, the founder of an institution of higher learning for African Americans, prominent local black educators, a local clergyman, a hero from the American Revolution, and, of course, President Lincoln were righteous examples. These individuals, who had worked within the system or were on the proper side of the struggle, were appropriate role models for African American children to emulate. The symbolic name changes, then, not only acknowledged the racial transition of a neighborhood and signified the conversion of a school from white to black use, but also the limited range of ambitions those names provided for the new students.

Essentially, the schools that served Kansas City's African American population in the segregated system were all named for individuals with whom the white, upper-class school board felt somewhat familiar and comfortable. Malcolm X understood this when he wrote about looking for a school named Lincoln in 1965. For this reason, it is likely that, had he given it much thought, Malcolm would have concluded that there was little possibility that he would ever be looking up the address for a school named in his honor in the Kansas City phone book. 